\title{
Hyponatremia in Chronic Liver Disease among Patients Presenting to a Tertiary Care Hospital: A Descriptive Cross-sectional Study
}

\author{
Abashesh Bhandari, ${ }^{1}$ Ashlesha Chaudhary ${ }^{2}$ \\ 'Department of Internal Medicine, Nepal Medical College and Teaching Hospital, Jorpati, Kathmandu, Nepal, ${ }^{2}$ Nepal \\ Medical College and Teaching Hospital, Jorpati, Kathmandu, Nepal.
}

\section{ABSTRACT}

Introduction: Hyponatremia is a frequent problem in chronic liver disease. To the best of our knowledge, no study of hyponatremia in chronic liver disease has been conducted in our setting. The aim of this study is to study the prevalence of hyponatremia in patients with chronic liver disease attending the outpatient department of a tertiary care hospital.

Methods: This descriptive cross-sectional study was conducted in 114 patients with chronic liver disease attending the out-patient department of a tertiary care hospital in Kathmandu, Nepal between November 2020 and July 2021. Ethical approval was taken from the Institutional Review Committee of Nepal Medical College and Teaching Hospital (Reference number: 028-077/078). Convenience sampling was done. The collected data was entered and analyzed in Microsoft Excel. Calculation of point estimate at $95 \%$ confidence interval was done along with frequency and proportion for binary data.

Results: Among the 114 patients with chronic liver disease studied, 47 (41.22\%) (32.18-50.25 at 95\% Confidence Interval) patients had hyponatremia $(\leq 130 \mathrm{mmol} / \mathrm{L})$ with mean age of $53.44 \pm 7.57$ years. Thirty (63.8\%) patients out of these were males and $17(36.2 \%)$ patients were females.

Conclusions: The prevalence of hyponatremia among patients with chronic liver disease was found to be higher when compared to other similar studies.

Keywords: hyponatremia; liver diseases; Nepal; sodium.

\section{INTRODUCTION}

Hyponatremia is common in patients with advanced stages of liver diseases. Patients with chronic liver disease (CLD) may develop hyponatremia due to either hypovolemia or hypervolemia. Hyponatremia in CLD is currently defined with a level of serum sodium less than $130 \mathrm{meq} / \mathrm{L}^{1}$

Studies have shown that the severity of the hyponatremia is related to the severity of the chronic liver disease..$^{2-4}$ However, Nepal's data on the occurrence of hyponatremia in chronic liver disease are scarce. ${ }^{5}$ To the best of our knowledge, no study of hyponatremia in chronic liver disease has been conducted in our setting.

The aim of this study is to study the prevalence of hyponatremia in patients with chronic liver disease attending the outpatient department of a tertiary care hospital.

\section{METHODS}

This is a descriptive cross-sectional study conducted among 114 patients with IBS presenting to the Department of Internal Medicine of a tertiary care hospital between November 2020 and July 2021. Ethical approval was taken from the Institutional Review Committee of Nepal Medical College and Teaching Hospital (Ref No: 028-077/078).

Patients who had given their consent were included in the study. The patients with Child Turcotte Pugh A score, compensated CLD, acute fulminant hepatitis, non-cirrhotic portal hypertension, chronic kidney disease and those who fail to give consent were excluded.

Correspondence: Dr. Ashlesha Chaudhary, Nepal Medical College and Teaching Hospital, Jorpati, Kathmandu, Nepal. Email: ashlesha04.ac@gmail.com, Phone: +9779813078654. 
Bhandari et al. Hyponatremia in Chronic Liver Disease among Patients Presenting to a Tertiary Care Hospital: A Descriptive...

The sampling method for this study was convenience sampling.

The sample size was calculated by using the formula,

$$
\begin{aligned}
\mathrm{n} & =\mathrm{Z}^{2} \times \mathrm{p} \times \mathrm{q} / \mathrm{e}^{2} \\
& =(1.96)^{2} \times 0.367 \times(1-0.367) /(0.09)^{2} \\
& =110
\end{aligned}
$$

Where,

$\mathrm{n}=$ required sample size

$Z=1.96$ at $95 \%$ Confidence Interval $(\mathrm{Cl})$

$\mathrm{p}=$ prevalence of hyponatremia in patients with chronic liver disease based on previous study ${ }^{6}$

$q=1-p$

$\mathrm{e}=$ margin of error, $9 \%$

A sample size of 114 patients was taken and detailed history with clinical examination were done. Informed consent from patients who were diagnosed with chronic liver disease was taken. Data regarding demographic variables, and varied presentation were documented. Around $5 \mathrm{ml}$ of whole blood, which was free from hemolysis was initially centrifuged at 3000 rates per minute at 10 minutes. The separated serum was analyzed for sodium levels using an automated electrolyte analyzer. Hyponatremia among these patients with chronic liver diseases were defined as a serum sodium level of less than $130 \mathrm{meq} / \mathrm{L} .{ }^{4}$

The data were entered into Microsoft Excel and descriptive statistics were calculated. Point estimate at $95 \%$ confidence interval was calculated along with frequency and proportion for binary data.

\section{RESULTS}

Among the 114 patients with chronic liver disease studied, 47 (41.22\%) (32.18-50.25 at 95\% Confidence Interval) patients had hyponatremia ( $\leq 130 \mathrm{mmol} / \mathrm{L}$ ) with mean age of $53.44 \pm 7.57$ years (Table 1 ).

\begin{tabular}{|llll|}
\hline \multicolumn{3}{|l|}{$\begin{array}{l}\text { Table 1. Levels of sodium and Child Pugh class } \\
\text { among patients with hyponatremia }(\mathbf{n}=47) \text {. }\end{array}$} \\
\hline & Hyponatremia & Child Pugh Class \\
& $\mathbf{n}(\%)$ & B & C \\
& & $\mathbf{n}(\%)$ & $\mathbf{n}(\%)$ \\
$\leq 125 \mathrm{mmol} / \mathrm{L}$ & $24(51.06)$ & $2(8.33)$ & 22 \\
& & & $(91.66)$ \\
$126-130 \mathrm{mmol} / \mathrm{L}$ & $23(48.93)$ & 5 & 18 \\
& & $(21.73)$ & $(78.26)$ \\
Total & $47(100)$ & $47(100)$ \\
\hline
\end{tabular}

The mean serum sodium levels among these patients was $124.85 \pm 3.27 \mathrm{mmol} / \mathrm{L}$. Thirty $(63.8 \%)$ patients out of these were males and $17(36.2 \%)$ patients were females. All of these patients had a history of alcohol consumption 47 (100\%). On upper gastrointestinal endoscopy of these patients, 45 (95.74\%) had varices.
The common clinical features in these patients were edema 47 (100\%), ascites 44 (93.6\%) and pallor 44 $(93.6 \%)$ as shown in the table below (Table 2 ).

\begin{tabular}{|ll|}
\hline \multicolumn{2}{|l|}{ Table 2. Clinical profile among patients of chronic liver } \\
disease with hyponatremia $(\mathbf{n}=\mathbf{4 7})$. \\
\hline Clinical Features & $\mathbf{n}(\%)$ \\
Icterus & $34(72.3)$ \\
Ascites & $44(93.6)$ \\
Edema & $47(100)$ \\
Upper Gastrointestinal Bleeding & $35(74.5)$ \\
Hepatic Encephalopathy & $22(46.8)$ \\
History of Hepatitis C & $0(0)$ \\
History of Hepatitis B & $10(21.3)$ \\
Pallor & $44(93.6)$ \\
Hepatorenal Syndrome & $22(46.8)$ \\
Spontaneous Bacterial Peritonitis & $13(27.7)$ \\
\hline
\end{tabular}

These patients were studied for various laboratory

\begin{tabular}{|c|c|}
\hline Laboratory Parameters & Mean \pm SD \\
\hline Total Leukocyte Count & $12770.42 \pm 7078$ \\
\hline Hemoglobin levels & $8.9 \pm 1.31$ \\
\hline Platelet count & $118535.85 \pm 149475$ \\
\hline Urea & $35.34 \pm 16.65$ \\
\hline Creatinine & $1.75 \pm 0.9$ \\
\hline Albumin & $2.56 \pm 0.356$ \\
\hline Total Bilirubin & $6.24 \pm 5.42$ \\
\hline Prothrombin Time (PT) & $21.21 \pm 3.07$ \\
\hline $\begin{array}{l}\text { Alanine Aminotransferase } \\
(\mathrm{ALT})\end{array}$ & $74.74 \pm 44.75$ \\
\hline $\begin{array}{l}\text { Aspartate Aminotransferase } \\
\text { (AST) }\end{array}$ & $127.53 \pm 48.86$ \\
\hline Alkaline phosphatase (ALP) & $207.53 \pm 62.74$ \\
\hline
\end{tabular}
parameters and their mean and standard deviation were expressed (Table 3).

\section{DISCUSSION}

Hyponatremia in chronic liver disease is a condition characterised by increased renal retention of water relative to sodium because of impairment in the clearance of solute-free water, which is frequent in individuals with cirrhosis and portal hypertension. ${ }^{1}$ Hyponatremia can be caused by a variety of reasons among these patients, the most common of which is increased arginine vasopressin secretion (AVP; also known as antidiuretic hormone, or ADH). AVP is considered to be released in portal hypertension via baroreceptormediated nonosmotic stimulation induced by a decrease in effective circulation volume, which is generated by arterial splanchnic vasodilation. ${ }^{1}$ Decreased production of solute-free water along with reduction in the delivery of sodium to the distal tubule secondary to reduction in the glomerular filtration rate as well as an increase in 
Bhandari et al. Hyponatremia in Chronic Liver Disease among Patients Presenting to a Tertiary Care Hospital: A Descriptive...

the sodium resorption in the proximal tubule are other factors that could be responsible.

Hyponatremia has been showed to cause increase the risk of mortality among individuals with cirrhosis, ${ }^{7,8}$ and in those patients who are on liver transplantation waiting lists. ${ }^{9}$ Its association with greater frequency and severity of complications of cirrhosis has been demonstrated in multiple studies. ${ }^{10-4}$ Singh JP, et al. in a study conducted among 60 patients with chronic liver disease showed $22(36.7 \%)$ patients had the serum sodium levels $<130 \mathrm{meq} / \mathrm{L}, 18$ (30\%) patients with serum sodium levels between 131-135meq/L and $20(33.3 \%)$ patients with serum sodium levels of $>135 \mathrm{meq} / \mathrm{L}$. Hepatic encephalopathy was seen in 21 patients with serum sodium levels $<130 \mathrm{meq} / \mathrm{L} .{ }^{6}$ Our study showed higher prevalence of hyponatremia ie. among the 114 patients studied, $47(41.22 \%)$ patients had hyponatremia ( $\leq 130 \mathrm{mmol} / \mathrm{L}$ ).

Younas A, et al. conducted a study in liver disease patients with hyponatremia, which showed serum sodium levels ranging from 115 to $127 \mathrm{meq} / \mathrm{L}$ (mean $121.41 \pm 5.17 \mathrm{meq} / \mathrm{L}) .{ }^{15}$ Low serum sodium levels was present among these patients in $96(36.9 \%)$ patients which was lower that what our study had showed. Fiftyone $(53.12 \%)$ patients among these were male and 45 $(46.8 \%)$ were female. Also, mild, moderate and severe hyponatremia among these was present in $24(9.2 \%)$, $56(21.5 \%)$, and $16(6.2 \%)$ patients respectively. The mean serum sodium levels among the patients of chronic liver disease with hyponatremia studied in our study was $124.85 \pm 3.27 \mathrm{mmol} / \mathrm{L}$. Comparable to this study, our study showed the prevalence of hyponatremia among the patients with liver disease to be higher among males.

In an international prospective study done in 28 liver units, among 997 patients the prevalence of hyponatremia where serum sodium concentration less than $135,130,125$, and $120 \mathrm{mEq} / \mathrm{L}$ in patients with liver disease was shown to be $50,22,6$, and 1 percent, respectively. ${ }^{10}$ Similarly, a total of 100 patients diagnosed with decompensated liver disease were included in another study by Devadas $A D$, et al. among which males constituted $80 \%$ and the rest were females. Sixty-seven\% of the patients were Alcoholics. HBsAg positive status was present in 11 patients, Hep C Positive status in 7 patients and, 15 patients were cryptogenic. In this study, hyponatraemia was seen in $70 \%$ of the patients which was higher as compared to our study. ${ }^{16}$

A case control study conducted by Shaikh S, et al. which involved 217 patients with chronic liver disease among whom hyponatremia (serum sodium $<130 \mathrm{meq} / \mathrm{l}$ ) was seen in $58(26.7 \%)$ patients and 54 (24.9\%) patients had serum sodium levels between 131-135 meq/l while 105 (48.4\%) patients had serum sodium levels $>135 \mathrm{meq} / \mathrm{l}$. Our study showed higher prevalence of hyponatremia among patients with chronic liver disease. Among the 114 patients studied, 47 (41.22\%) patients had hyponatremia ( $\leq 130 \mathrm{mmol} / \mathrm{L}$ ). ${ }^{17}$

A study was carried out among 754 patients in the Manipal College of Medical Sciences and Teaching Hospital, Nepal which was a descriptive crosssectional study and showed the prevalence of hyponatremia $(<130 \mathrm{mEq} / \mathrm{L})$ in hospitalized patients with decompensated liver disease to be 176 (23.34\%), which was lower as compared to the finding from our study. ${ }^{5}$

Borroni G, et al. conducted a study which showed that out of 191 admissions, hyponatremia was seen in $97(29.8 \%) .{ }^{18} \mathrm{Kim} \mathrm{JH}$, et al. found the prevalence of dilutional hyponatremia, with the serum sodium levels of $\leq 135 \mathrm{mmol} / \mathrm{l}$, $\leq 130 \mathrm{mmol} / \mathrm{l}$ and $\leq 125 \mathrm{mmol} / \mathrm{l}$, to be $20.8 \%, 14.9 \%$ and $12.2 \%$ respectively. ${ }^{11}$

A study on 997 patients with chronic liver disease was carried out by Angeli $P$, et al. which found out that the prevalence of hyponatremia as defined by a serum sodium concentration $\leq 135 \mathrm{mmol} / \mathrm{l}$, $\leq 130$ $\mathrm{mmol} / \mathrm{l}$, $\leq 125 \mathrm{mmol} / \mathrm{l}$ and $\leq 120 \mathrm{mmol} / \mathrm{l}$ was $49.4 \%$, $21.6 \%, 5.7 \%$, and $1.2 \%$, respectively. ${ }^{10}$ Hyponatremia has been clearly documented as an independent risk factor for mortality and is prevalent in individuals with end-stage liver disease. ${ }^{19}$ Low serum sodium levels have been demonstrated to have a significant negative influence on the quality of life in individuals with chronic liver disease and ascites. ${ }^{20} \mathrm{~A}$ history of encephalopathy, serum creatinine, and bilirubin are all prognostic markers for the development of overt hepatic encephalopathy, as is hyponatraemia with serum sodium $\leq 130 \mathrm{mEq} / \mathrm{L} .{ }^{21}$

Small sample size and sampling bias could be the major limitation in our study. Similarly, various other pathologies that could cause hyponatremia could coexist in these patients which would affect the real picture of hyponatremia among patients with chronic liver disease. As this is a descriptive cross-sectional study, association between the low serum sodium levels and chronic liver disease could not be made. Also, the single center nature of this study limits the generalizability of the findings. Therefore, higher studies are warranted for the finding out the real picture of prevalence, association and causality among Nepalese population.

\section{CONCLUSIONS}

The prevalence of hyponatremia among patients with chronic liver disease was found to be higher when compared to other similar studies. Association of hyponatremia in patients with chronic liver disease needs 
Bhandari et al. Hyponatremia in Chronic Liver Disease among Patients Presenting to a Tertiary Care Hospital: A Descriptive...

to be tested using higher study designs to establish causality in our setting. Hyponatremia in patients with chronic liver disease is correctable and timely correction could improve their functional status and quality of life and decreases morbidity and mortality.

Conflict of Interest: None.

\section{REFERENCES}

1. Gines P, Berl T, Bernardi M, Bichet DG, Hamon G, Jimenez $\mathrm{W}$, et al. Hyponatremia in cirrhosis: from pathogenesis to treatment. Hepatology. 1998 Sep;28(3):851-64. [람ed | Full Text | DOI]

2. Attar B. Approach to Hyponatremia in Cirrhosis. Clin Liver Dis (Hoboken). 2019 Apr 30;13(4):98-101. [라Med | Full Text | DOI]

3. John S, Thuluvath PJ. Hyponatremia in cirrhosis: pathophysiology and management. World J Gastroenterol. 2015 Mar 21;21(11):3197-205. [PubMed | Full Text | DOI]

4. Ginès $\mathrm{P}$, Guevara $\mathrm{M}$. Hyponatremia in cirrhosis: pathogenesis, clinical significance, and management. Hepatology. 2008 Sep;48(3):1002-10. [PubMed | Full Text | DOI]

5. Bhattarai S. Complications and Mortality in Hospitalised Patients With Decompensated Cirrhosis of Liver in a Tertiary Care Centre in Nepal. Cureus. 2020 Aug 24;12(8):e9996. [PubMed | Full Text $\mid \underline{\text { DOI] }}$

6. Singh JP, Khurana A, Singh D. Frequency of hyponatremia and its influence on liver cirrhosis- related complications. Int J Adv Res. 2016;4(2):1113-8. [Full Text]

7. Llach J, Gines P, Arroyo V, Rimola A, Tito L, Badalamenti $S$, et al. Prognostic value of arterial pressure, endogenous vasoactive systems, and renal function in cirrhotic patients admitted to the hospital for the treatment of ascites. Gastr oenterology. 1988;94(2):482-7. [PubMed | Full Text | DOI]

8. Fernandez-Esparrach G, Sanchez-Fueyo A, Gines P, Uriz J, Quinto L, Ventura PJ, et al. A prognostic model for predicting survival in cirrhosis with ascites. J Hepatol. 2001 Jan;34(1):46-52. [

9. Kim WR, Biggins SW, Kremers WK, Wiesner RH, Kamath PS, Benson JT, et al. Hyponatremia and mortality among patients on the liver-transplant waiting list. N Engl J Med. 2008 Sep 4;359(10):1018-26. [․ㅏbMed | Full Text | DOI]

10. Angeli P, Wong F, Watson H, Gines P. CAPPS Investigators. Hyponatremia in cirrhosis: Results of a patient population survey. Hepatology. 2006 Dec;44(6):1535-42. [ubMed | Full Text | DOI]

11. Kim JH, Lee JS, Lee SH, Bae WK, Kim N-H, Kim K-A, et al. The association between the serum sodium level and the severity of complications in liver cirrhosis. Korean J Intern Med. 2009;24:106-12. [PubMed | Full Text | DOI]

12. Londono MC, Guevara M, Rimola A, Navasa M, Taura P, Mas
A, et al. Hyponatremia impairs early posttransplantation outcome in patients with cirrhosis undergoing liver transplantation. Gastroenterology. 2006 Apr;130(4):1135-43. [PubMed | Full Text | DOI]

13. Hackworth WA, Heuman DM, Sanyal AJ, Fisher RA, Sterling RK, Luketic VA, et al. Effect of hyponatraemia on outcomes following orthotopic liver transplantation. Liver Int. 2009 Aug;29(7):1071-7. [uued | Full Text | DOI]

14. Weismüller TJ, Fikatas P, Schmidt J, Barreiros AP, Otto G, Beckebaum S, et al. Multicentric evaluation of model for end-stage liver disease-based allocation and survival after liver transplantation in Germany--limitations of the 'sickest first'-concept. Transpl Int. 2011 Jan;24(1):91-9. [PubMed | Full Text | DOI]

15. Younas A, Riaz J, Chughtai T, Maqsood H, Saim M, Qazi $\mathrm{S}$, et al. Hyponatremia and Its Correlation With Hepatic Encephalopathy and Severity of Liver Disease. Cureus. 2021 Feb 6;13(2):e13175. [PubMed | Full Text | DOI]

16. Devadas AD, Srividya, Raja G, Kumar S, Sindhu, Shanmugasundaram, et al. A Study on Hyponatremia in Decompensated Liver Disease. J Med Sci Clin Res. 2017 Apr;5(4):19832-6. [ Full Text | DOI]

17. Shaikh S, Mal G, Khalid S, Baloch GH, Akbar Y. Frequency of hyponatraemia and its influence on liver cirrhosis-related complications. J Pak Med Assoc. 2010 Feb;60(2):116-20. [PubMed | Full Text]

18. Borroni G, Maggi A, Sangiovanni A, Cazzaniga M, Salerno F. Clinical relevance of hyponatraemia for the hospital outcome of cirrhotic patients. Dig Liver Dis. 2000 Oct;32(7):605-10. [PubMed | Full Text | DOI]

19. Arroyo V, Rodes J, Gutierrez Lizarraga MA, Revert L. Prognostic value of spontaneous Hyponatremia in cirrhosis with ascites. Am J Dig Dis. 1976;21(3):249-56. [PubMed | Full Text | DOI]

20. Solà E, Watson H, Graupera I, Turon F, Barreto R, Rodríguez E, et al. Factors related to quality of life in patients with cirrhosis and ascites: relevance of serum sodium concentration and leg edema. J Hepatol. 2012 Dec;57(6):1199-206. [PubMed | Full Text | DOI]

21. Guevara M, Baccaro ME, Torre A, Gomez-Anson B, Ríos J, Torres F, et al. Hyponatremia is a risk factor of hepatic encephalopathy in patients with cirrhosis: a prospective study with time-dependent analysis. Am J Gastroenterol. 2009 Jun;104(6):1382-9. [PubMed | Full Text | DOI]

\section{The Author(s) 2018}

This work is licensed under a Creative Commons Attribution 4.0 International License. The images or other third party material in this article are included in the article's Creative Commons license, unless indicated otherwise in the credit line; if the material is not included under the Creative Commons license, users will need to obtain permission from the license holder to reproduce the material. To view a copy of this license, visit http://creativecommons.org/licenses/by/4.0/ 